\title{
Repeat the Song! The Psalms and the Eucharist
}

\section{The Revd Dr Megan Daffern}

Oxford University

\begin{abstract}
In prayer and ritual, time and eternity intersect. The theology of time is a lens through which such comparable texts may be examined. Time is also a means for reflecting on hermeneutic method in studying prayer texts. This article explores time and eternity in both the prayer texts and the study of the prayer texts of the Psalms and the Eucharist, with reference to the work of Eliade, Levine, and Begbie. The two prayer texts, and the three theologians, thus contribute much to the interpretation of one another when read together.
\end{abstract}

\section{Keywords}

Psalms, Eucharist, memory, prayer, time, repetition 


\section{Introducing the Dialogue}

Sacred time is indefinitely recoverable, indefinitely repeatable. 'Reversibility,' 'reintegration,' 'reactualization,' 'recoverability,' 'repeatability' - all of these parallel words in Eliade's vocabulary point to what he considers to be the central fact about sacred time. It does not pass away. It existed before, as first instituted by the gods or God, and it will continue to exist into the future, as ensured by the traditions of religious ritual. The problem of irreversible time, which is coterminous with human existence in the world, is resolved by the mediation of religion, whose root meaning, of course, is 'to connect again.' 1

In the midst of our fractured and distorted temporality we are given to participate in a temporality in which our past, present, and future can be at peace, co-inhere. ${ }^{2}$

Before the mountains were begotten or you brought to birth the earth and the world, from everlasting to everlasting you are God. ${ }^{3}$

This cup is the new covenant in my blood. Do this, as often as you drink it, for my remembrance. $^{4}$

\footnotetext{
${ }^{1}$ Herbert J. Levine, Sing Unto God a New Song: A Contemporary Reading of the Psalms (Indianapolis: Indiana University Press, 1995), 131.

${ }^{2}$ Jeremy Begbie, Theology, Music and Time, Cambridge Studies in Christian Doctrine (Cambridge: CUP, 2000), 173.

${ }^{3}$ Ps 90:2. All translations are the author's own.

${ }^{4} 1$ Cor 11:25.
} 
Herbert Levine's adoption of the perspective of sacred time in the works of Mircea Eliade parallels the adoption of the divine perspective of time in the Psalms, which in turn prefigures the intrusion of divine eternity reincarnated time and again in the performance of the Eucharistic words. Eliade, a philosopher and historian of religious experience, repeatedly ponders the mysteries of time in the world's religions. Levine hints at the potential of the Psalms as ritual and repetitive prayer. Begbie examines the power of the sacred in overcoming the brokenness of time-bound existence in the celebration of the Eucharist. These writers and prayer texts are therefore here brought into dialogue to explore not only their intersections, but also the intersection of time and eternity.

\section{Time and Eternity in Ritual: Eliade}

Eliade's distillation of sacred time runs:

...by its very nature sacred time is reversible in the sense that, properly speaking, it is a primordial mythical time made present. Every religious festival, any liturgical time, represents that reactualization of a sacred event that took place in a mythical past, "in the beginning." Religious participation in a festival implies emerging from ordinary temporal duration and reintegration of the mythical time reactualized by the festival itself. Hence sacred time is indefinitely recoverable, indefinitely repeatable... Hence religious man lives in two kinds of time, of which the more important, sacred time, appears under the paradoxical aspect of a 
circular time, reversible and recoverable, a sort of eternal mythical present that is periodically reintegrated by means of rites. ${ }^{5}$

Carl Olson understands Eliade in terms of a 'theology of nostalgia': the desire to 'return to an idyllic age' or to 'a kind of paradise where communication existed between heaven and earth' may be fulfilled. 'By an indefinitely repeated invocation of archetypes, homo religiosus could remain near the real and meaningful'. ${ }^{6}$ Olson himself appears influenced by Eliade's ritual interpretations. Reflecting on the Sabbath and how the repeated enactment of this Hebrew Biblical injunction points to the importance of remembered and remembering time in man's relationship with God, he later writes: 'Liturgy creates and shapes memory, which in turn shapes our core commitments, actions, and beliefs. ${ }^{7}$

Prayer in the Psalms often involves remembering, at multiple levels of the text.

Textual and semantic analysis has demonstrated that Hebrew remembering in prayer can be said to be relational, actualizing, and effective. ${ }^{8}$ The experience of remembered times, remembered divine-human relationships, and remembered prayer in the Psalms thus resonates with - even exemplifies - Eliade's understanding of sacred time. 'Primordial mythical time', or illud tempus, is in Hebrew prayer not only a time-bound primordial

\footnotetext{
${ }^{5}$ Mircea Eliade, The Sacred and the Profane: The Nature of Religion, trans. Willard R. Trask (London: Harcourt Brace, 1987), 68-70.

${ }^{6}$ Carl Olson, The Theology and Philosophy of Eliade: A Search for the Centre (Basingstoke: Macmillan, 1992), 57.

${ }^{7}$ Dennis T. Olson, "Sacred Time: The Sabbath and Christian Worship," in Touching the Altar: The Old Testament for Christian Worship, ed. Carol M. Bechtel (Grands Rapids: Eerdmans, 2008), $18 .$.

${ }^{8}$ Megan I. J. Daffern, J. Barton, and D. F. Cram, "Prayers for Remembering in the Psalms" (Oxford, 2014); Brevard Childs, Memory and Tradition in Ancient Israel (London: SCM, 1962); P. A. H. de Boer, Gedenken Und Gedächtnis in Der Welt Des Alten Testament (Stuttgart: W. Kohlhammer, 1962); Willy Schottroff, 'Gedenken' Im Alten Orient Und Im Alten Testament: Die Wurzel ZāKar Im Semitischen Sprachkreis (Neukirchen-Vluyn: Neukirchener, 1964); H. Eising, "ZāKar, ZēKer, ZikkāRôN, AzkāRâ," in Tdot, ed. G. Johannes Botterweck, Helmer Ringgren, and Heinz-Josef Fabry (Grand Rapids: Eerdmans, 1974).
} 
myth that is remembered and reactualized, but even a primordial divine-human relationship. Thus when Eliade's paradigm is linked with the Psalms, this primordial myth encapsulates not only the creation myths but also the covenant literature and the sense of ongoing creation: above all, it points to an ongoing relationship as remembered and continually relived as well as a mythical moment in time that is pursued again and again. Primordial mythical time, paradise, or illud tempus, for which the pray-er yearns, involves communication and near-ness between man and God.

That yearning for a primordial time when the divine-human relationship was complete and perfect, when God was the unassailable king, when righteousness reigned supreme without exception, is clearly indicated by the repeated re-enactment of the Psalms in the cult. While form-critics debate the specific Sitz-im-Leben of many psalms (arguably itself a mythical illud tempus which later generations continually seek to recapture), the very tradition, remembering and continued re-performance of the Psalms illustrate that nostalgia. Each performance of praise or prayer was a reactualization of that primordial relationship, a returning to and recapitulation of right relationship between God and man. It was the human response to the repeated divine offering of grace in covenant renewed. Hence Eliade later writes:

It may, then, be said with truth that the Hebrews were the first to discover the meaning of history as the epiphany of God, and this conception, as we should expect, was taken up and amplified by Christianity. ${ }^{9}$

\footnotetext{
${ }^{9}$ Eliade, The Sacred and the Profane: The Nature of Religion, 104.
} 
Eliade develops his thinking from a philosophy to a theology of history where the incarnate God of Christianity sanctifies time. As the Christian participates in liturgical reactualization of the illud tempus of Jesus Christ's birth, death, and resurrection, such historical times become theophany re-experienced. The history in which God has participated and revealed himself has a 'trans-historical purpose - the salvation of man'. 10

Time is itself effectively transcended as history is sanctified by theophany and its liturgical reactualization. Thomas Altizer, writing on Eliade's concept of time, highlights the connection made with Kierkegaard that 'eternity is the true repetition'. ${ }^{11}$ Time and eternity are both intimately present in the prayer texts of the Psalms.

\section{Time and Eternity in Prayer Texts: Levine and Psalms 90 and 145}

Levine's reflections on Eliade, quoted above, accentuate how the worldly time-frame in which prayer is made reaches toward this sacred time, the eternity of God. He later writes:

the collective memory of ritual helps a people overcome time's irreversible flow by allowing it to repeat in historic time acts originating in mythical time. Acts of private memory, as we see in this context, can make time similarly malleable, subject to the reinterpretation of a new perspective on life. ${ }^{12}$

\footnotetext{
${ }^{10}$ Ibid., 110-2.

${ }^{11}$ Kierkegaard, Repetition, xxii, cited in Thomas J. J. Altizer, Mircea Eliade and the Dialectic of the Sacred (Philadelphia: Philadelphia : Westminster Press, 1963), 54.

${ }^{12}$ Levine, Sing Unto God, 156.. 'Wisdom' could thus also be considered a means of challenging time.
} 
Repetition and memory, as themes explored in relation to Eliade, can be analysed in ritual texts, remembered prayer texts such as the Psalms. Levine on the Psalms indicates how memory can make time malleable and therefore go beyond an earthly perception of time to a sacred perspective on time. This is relevant in prayer both public and private, referring to everything from specific historical events, particular times of day, week, and year, to the succession of the generations. If indeed 'eternity is the true repetition', then memory is clearly a means by which time intersects with eternity. Past events, although physically unrepeatable, such as creation, the Exodus, the destruction of the Temple, are made repeatable in prayer. They become part of the present and future of the worshipping community and individual. Times which are essentially repeatable, the time of days and seasons and festivals, become the stable repetitive heartbeat within which shared memory reconstructs time. The times of generations past and future are the security of an ongoing voyage into sacred time, the continuous engagement of time and eternity.

Old and new are both valuable here. 'A sharp dichotomy between the old and the new, or between the traditional and the innovative, can rarely be sustained. ${ }^{13}$ Levine's liminality of the Psalms, prayer as standing on not only the threshold of the inner sanctum, but also on the cusp of old and new, past and future, unfolds this further. ${ }^{14}$ The understanding of the Psalter as a collection of 'liminal' texts reverberates with Brueggemann's recent reading of the creativity in these prayer texts:

\footnotetext{
${ }^{13}$ Although written with reference to Socrates, this dictum resonates here. Armand D'Angour, The Greeks and the New: Novelty in Ancient Greek Imagination and Experience (Cambridge: CUP, 2011), 24.

${ }^{14}$ Levine, Sing Unto God, 53.
} 
The Psalter... is inherently subversive because it tells insistently and relentlessly against every closure. It speaks a sub-version of reality that inescapably will subvert settled versions of theology, politics, or economics. That subversion is the voice of protest that will not settle for any unjust worldly arrangement; but that subversion is also the voice of wonder that acknowledges and celebrates new gifts, new life, and new miracles beyond all that the rulers of this age can manage and administer. That subversion is an act of insistent imagination. ${ }^{15}$

The Psalter is the voice of the past, remembered, repeated, and therefore sustained in present and future. It looks forwards as well as back, but it does yet more: it challenges both what has been, what is being, and also what will be perceived and experienced, and in doing so it refuses to be contained and bounded. In another way, then, the Psalms reach from worldly time-bound experiences to sacred time and infinite eternity.

This 'speaking against endings' necessitates the text having different audiences through the ages and therefore emphasises the nature of the Psalms as texts that were designed to be memorable and were intended to exist through many generations. They were to shape the community through the years. They were to continually challenge the past and look ever forwards to the new, tying in with the difference between 'real' and 'implied' audiences. ${ }^{16}$

${ }_{15}$ Brueggemann in Joel S. Burnett, W. H. Bellinger, and W. Dennis Tucker, Diachronic and Synchronic: Reading the Psalms in Real Time, Baylor Symposium on the Book of Psalms (London: T\&T Clark, 2008), 12.

${ }^{16}$ Bridget Gilfillan Upton, Hearing Mark's Endings: Listening to Ancient Popular Texts through Speech Act Theory (Leiden: Brill, 2006), 102-4; Seymour Chatman, Story and Discourse: Narrative Structure in Fiction and Film (Ithaca, NY: Cornell University Press, 1978). 
The Psalms were therefore passed down from one generation to another, whether informally through repetition in communal worship, or formally in study. ${ }^{17}$ Speakers - or pray-ers - of these texts, and their audiences or congregations, would be continually changing throughout the years, as students became teachers, and those led in worship became leaders of worship. So even though, as subversive texts, the use of the Psalms was and is ongoing and repeated, each repetition, each performance, naturally had a beginning and an end. Each performance was itself momentary, pointing to how Scripture was meant to be reiterated. ${ }^{18}$

Old and new, past and future: reception history points to how these prayer texts were used and re-used throughout different historical eras and traditions. ${ }^{19}$ Memory in and of the Psalms is an iterative tool, a creative means of reactualization and repetition by which text, prayer, and the relationship between God and man may persist.

All acts of remembering in prayer, and remembered prayers, are set in the Psalms in the context of an eternal God. Words for eternity recur in the Psalter, often in contrast with limited humanity. Humanity and divinity come close in times of prayer and worship; just so human time intersects with divine eternity. ${ }^{20}$ Historical, physically unrepeatable times, become repeatable in memory and prayer: offered to God, sanctified in his presence, they become petitions that such experiences might never be repeated. By such

\footnotetext{
${ }^{17}$ B. Gerhardssen, Memory and Manuscript: Oral Tradition and Written Transmission in Rabbinic Judaism and Early Christianity; with Tradition and Transmission in Early Christianity (Grand Rapids: Eerdmans, 1998).

${ }^{18}$ Begbie's work on music and time in theology points towards this perception of Scripture as a timebound text, existing at a moment of performance yet with the expectation of iteration. Begbie, Theology, 31.

${ }^{19}$ S. E. Gillingham, Psalms through the Centuries, vol. 1 (Oxford: Blackwell, 2008); S. E. Gillingham, A Journey of Two Psalms: The Reception of Psalms 1 and 2 in Jewish and Christian Tradition (Oxford: OUP, 2013); S. E. Gillingham, ed. Jewish and Christian Approaches to the Psalms: Conflict and Convergence (Oxford: OUP, 2013).

${ }^{20}$ Levine, Sing Unto God, 131.
} 
retelling, the memory becomes part of both present and future of both worshipping community and individual. Repeatable times in the cult, such as the time of days and seasons and festivals, offer a framework of prayer within which memory reconstructs time. Repetition and remembrance offer a finite but indefinitely repeatable means of engaging mortal time with divine eternity.

Grounded in the past, the Psalms look to the future. Speaking from the old, they always hope for the new. They often desire the 'old' to be over, the past to be passed indeed, that change and new life may come about. Past, present, and future, are all experienced in the present. A prayer text exists in time and speaks of time; its performance both consists in and is constrained by time; its ongoing tradition endures through time; while its divine subject, audience and addressee, is eternal. For Augustine reading the Psalms, time allowed for anticipation as well as repetition, expectation as well as memory. ${ }^{21}$ Two texts - Psalms 90 and 145 - will illustrate and explore this notion more fully.

\section{Psalm 90}

'A Song of Moses': the very superscription to Ps 90 demonstrates the different contexts of composition and performances of the prayer as repeated. ${ }^{22}$ The opening verses of Book IV of the Psalter display the tension between time-bound humanity and infinite divinity,

\footnotetext{
${ }^{21}$ Indeed Augustine ties both past and future together in his description of the process of reading a Psalm, Confessions XI.28.38.

22 'If this psalm is indeed Mosaic, its view of time may well reflect a sense of the oneness of the generation of the exodus with the patriarchs, all set against the ultimate background of the creation... [Although the provenance of the superscription itself is queried] a number of recent scholars... have seen the aptness of a reference to Moses in its superscription.' Geoffrey Grogan, Psalms (Grand Rapids: Eerdmans, 2008), 158; A. A. Anderson, The Book of Psalms, New Century Bible (London: Oliphants, 1972), 649. makes a similar observation.
} 
resonating with Gen 2-3, 5. The Psalmist recognises that the years of mortal life are but fleeting alongside the eternity of God. For humanity, a thousand years is a span of many generations (v.4); for God, this is of no more significance than a day, or a part of the night. Rich imagery unfolds this contrast. God is capable of brushing years away just as dreams in one's sleep vanish with the morning (v.5). For the God of the Psalms, time is shown to be of little import: like grass, mortal experience of time is as insignificant as the most common, simplest plant in the meadow, fragile and with the shortest life-span imaginable (v.6). Under the wrath and justice of God, sinful man is weak and short-lived. Life and years are extinguished with little more than a sigh (v.9). Even the calculations of a long life (v.10), with lengths of time added one upon another, 'the days of our years' are only hard work, and men's lives 'fly away', bearing the image of lightness and inconsequentiality in contrast to the heaviness of life on earth.

Poetic illustration is now focused in the repeated language of 'days': even the longest-lived of mortals is nothing beside the eternal God. Humanity measures itself in terms of days, parts of days, the smallest measurements of time thus far in the Psalm. Valuing the present moment, recognising his own limitedness, the mortal grows in wisdom (v.12). The plaintive query 'How long?' demonstrates the psalmist maturing in humility, recognizing that his times are all in the hand of God. With the language of morning juxtaposed with God's steadfast love (v. 14), the Psalmist intimates that the daily refreshing of human experiences of God will make the present moment nourishing for the future. Humanity's past is balanced with humanity's future (v.15): the hope is now that past days and years of suffering will be recompensed by God with an equal measure of gladness. If this is so, God's glory will be evident not only for his people in the 
present, but also their growing and future offspring (v.16). Thereby offering a rationale to God why he should grant this prayer, the Psalmist crescendoes to the ultimate climax of petition in repetitive phrases in the final verse (v.17), in contrast with the heaviness of hard work endured (v.10). Mortal years and days are shortened against the divine perspective, extended against the future of generations who will praise God, and finally pin-pointed to the manual actions of the present human moment.

\section{Psalm 145}

Ps 145 exemplifies the Psalmist as leader of praise both in time and through the ages. The phrase 'for ever and ever' occurs thrice in emphatic position at the end of verses 1,2 , and 21; God's kingdom is also described as 'an everlasting kingdom' (v.13). The Psalmist is insistent: he will extol God (v.1), bless him (vv.1 and 2), praise his name (v.2). Thereby both presently enacting this praise, and committing to it for the future, the Psalmist is further causing continuing praise of God in the repetition of the prayer as long as the psalm itself exists. Promising praise on behalf of all coming people of Israel, the Psalmist is confident that these prayers will endure, by means of the repetition and transmission of the text from one generation to the next. ${ }^{23}$ Indeed the Psalm's acrostic structure, and position at what may once have been the final text in the collection, provides a memorable summary of the Psalter's teaching about God. ${ }^{24}$

\footnotetext{
${ }^{23}$ Indeed this text could be seen as an effective outworking of the covenant; so Weiser and Anderson are able to link it with the 'feast of the covenant' and the 'feast of tabernacles'. Anderson, Psalms, 936.

${ }^{24}$ Grogan, Psalms, 223; James Luther Mays, Psalms, Interpretation (Louisville: John Knox Press, 1994), 439; Walter Brueggemann and William H. Bellinger, Psalms, New Cambridge Bible Commentary (New York: Cambridge University Press, 2013), 603-4. '... [it expresses] a totality, in this case the complete praise of God.' Frank-Lothar Hossfeld et al., Psalms 3: A Commentary on Psalms 101-150, Hermeneia (Minneapolis: Fortress Press, 2011), 593.
} 
The change in voice in 145:4, the 'they' of future generations, or the unspecified worshippers of the passive voice of praise of God, achieves manifold effects. There is the ease of ownership of this psalm: the Psalms is designed that anyone can pray it. Such potential popularity will enable the psalm to be more readily transmitted through the centuries. Furthermore, the psalmist locates himself within the congregation, somehow responsible for the praise that is offered, not simply now, but in future generations. His meditations, his declarations, enable the congregation to worship. The progression of thought throughout verses 5-7 show the psalmist's own private worship as intertwined with, and the backbone of, the public voice of praise.

This is relevant not just to all people, but to all of creation (v.9). All God's creatures are to engage in this ongoing praise. Creation's praise of God itself reveals God's glory to generations of mortals, 'sons of Adam' (v.12). This celebrated 'memorial' of God (v.7) can be transmitted through the centuries forever: if God's people continue to remember God, both he and they will endure. Praise is central to existence: the wellbeing of man, or even every living thing, is further something to which God is committed by this enduring praise (vv.14-16). The wicked, set up in contrast to the faithful who remember God and praise him, yet will be destroyed (v.20): their own memorial is destruction, for they have not reiterated the community memory of God in praise. The interchanging individual and communal voices of everlasting praise are neatly tied together at the psalm's end (v.21) as the present once again intersects with eternity.

Remembering thus paradoxically becomes less time-bound, as the illud tempus of the psalm itself is swathed in the perpetuity of its message and ongoing enactment of praise. One moment of prayer is enshrined for generations: this is a text cherished by a 
people wishing thus to survive themselves, as individuals and as a nation, and ultimately related to this, wishing their God - committing their God? - also to survive.

These two texts, necessarily selected from a large number of possible contenders, most pithily express some of the theology of time and remembering in the prayer texts of the Psalms. Eternity is not only to be remembered as something divine, something God's people yearn to experience in their prayers; it is also an eternity of remembering, unlimited space and time for remembering. Through remembering and repetition, God's eternity is experienced and continually remembered. Man and God are together implicated in Levine's 'collective memory of ritual'.

\section{Time and Eternity in Prayer Texts: Begbie on the Eucharist}

The renowned ambiguity of the words of institution repeated in each and every celebration of the Eucharist echoes this intertwining of God's and man's ongoing commitment to enact remembrance. ${ }^{25}$ Time, eternity, repetition and remembrance are indivisible from concepts of past, present and future, relevant to the Psalms as well as to the Eucharist. Augustine's reflections on reading a psalm were that 'the scope of the action which I am performing is divided between the two faculties of memory and expectation, the one looking back to the past which I have already recited, the other looking forward to the part which I have still to recite'. ${ }^{26}$ This gives rise to the distentio

\footnotetext{
${ }^{25}$ I will not rehearse the liturgical theological background here: a varied selection of seminal works will include Gregory Dix, The Shape of the Liturgy, New edition. ed. (London : Bloomsbury T\&T Clark, 2015); Joachim Jeremias, The Eucharistic Words of Jesus (London: SCM, 1966); Julie Gittoes, Anamnesis and the Eucharist: Contemporary Anglican Approaches (Aldershot: Ashgate, 2008). See also New Testament studies on the Biblical mandate.

${ }^{26}$ Aug. Conf. XI.28.38 cited in Begbie, Theology, 78.
} 
animi on which much modern philosophy of time is built. ${ }^{27}$ Thus, 'we cannot speak meaningfully of things which no longer exist as existing now except in memory, nor of this not yet existing as existing except in expectation. ${ }^{, 28}$ I have briefly explored how what is past, present, and future, is at one and the same time distinct, yet experienced all in the present, with respect to the Psalms; similar themes are evident in reflecting on the Eucharist.

Jeremy Begbie treats just such themes, culminating in a study of the Eucharist. What he says of the relationship between time and the Eucharist can be considered true also of the relationship between time and prayer in the Psalms. Thus the Psalms reflect much of the same thinking on time and prayer as was instituted in the Eucharist. In a way, then, the Psalms may be viewed as a tupos or precursor of the prayer that is to come in the NT. ${ }^{29}$

Connecting Begbie's work in general with Psalm texts themselves is methodologically straightforward: the Psalms were sung, and were composed to be sung. ${ }^{30}$ To consider them simply as poetry is like studying an opera only as a text, even though little may be known of the music and tonality of the psalms. They were also performed as prayers, often in public contexts whereby they might be remembered and transmitted. Oral performance takes time: time lapses between the beginning and end of

\footnotetext{
${ }^{27}$ Paul Ricœur, Time and Narrative, 3 vols. (Chicago: University of Chicago Press, 1984-1988), $16 .$. Cited in Begbie, Theology, 77.

${ }^{28}$ Begbie, Theology, 63.

${ }^{29}$ Ps 145 itself may also be viewed as a precursor to Jesus's institution of the Lord's Prayer. See John Goldingay, Psalms, vol. 3, Baker Commentary on the Old Testament Wisdom and Psalms (Grand Rapids: Baker Academic, 2008), 705; Hossfeld et al., Psalms 3, 603.

30 As reflected for instance in the superscriptions. Cf. J. H. Eaton, Psalms: Introduction and Commentary (London: SCM, 1967), 9-13.
} 
that performance. ${ }^{31}$ Texts - whether the Psalms or liturgical texts built around dominical commands - exist all at the same time, even if their reading does not. Thus both texts have the performative possibilities that 'the word changes the world' ${ }^{32}$ Considering the performance of the Psalms contributes considerably to understanding the texts as effective prayer texts that are repeated and both time-bound yet also timeless.

Indeed performance of a text is not a one-dimensional linearity, but it involves 'different kinds of temporal succession, which intersect, interpenetrate and enhance one another as the music unfolds. ${ }^{33}$ Similarly, different readings of the Psalms are not mutually exclusive, given that different kinds of succession, continuity, discontinuity, and so on may exist side-by-side. In fact, different interpretations, arising from different historical, social and cultural contexts, will ideally be read together, in so far as this reflects the 'multiplicity of temporal continua operating concurrently' ${ }^{34}$ that is experienced both in music and in our human perception of time more broadly.

Begbie gives five broad statements about the performance of the Eucharist. 'Eucharistic repetition both stabilises and destabilises'; 'Eucharistic repetition can "go flat"'; 'Eucharistic repetition does not efface the temporal integrity of the initial appearance of the theme, or of its repetitions'; 'Eucharistic repetition means improvising'; and 'Eucharistic repetition depends on and enables a particular kind of interpenetration of past, present, and future.' I will deal with each of these in turn, relating Begbie's reflections to the Psalms.

\footnotetext{
31 'The production and reception of music deeply implicates physical realities and these realities are themselves time-laden.' Begbie, Theology, 31.

${ }^{32}$ A. C. Thiselton, New Horizons in Hermeneutics (London: Harper Collins, 1992), 298-307..

${ }^{33}$ Begbie, Theology, 35.

${ }^{34}$ Ibid.
} 


\section{(i) 'Eucharistic repetition both stabilises and destabilises'.}

Begbie illustrates this with reference to repeated phrases in music simultaneously increasing tension and effecting resolution. ${ }^{35}$ In the Eucharist, he contends, stability is brought about by God's re-calling his people to 'know again the transforming power of the cross'. Yet there is also destabilising power here: 'to be opened out repeatedly to Christ's past is to be opened out to a future anticipated in him, and thus ... to be incorporated into a forward momentum of the Spirit which activates in us an increased longing... ${ }^{36}$ Stability and instability are related to the contrasts between mortal and divine time in the Psalms; stability is experienced in the repetitive and communal memory of prayer, while it is challenged in the language of lament and the questioning 'how long?' There is yearning and hope alongside lament and despair, ${ }^{37}$ leading to an ongoing questioning and deepening understanding of God that does not risk abstraction of the present unconnected with past and future. ${ }^{38}$

\section{(ii) 'Eucharistic repetition can "go flat"'.}

Repeated phrases in music 'invite or retain interest' yet also risk feeling 'mechanical or dull'. Repetition of the Eucharist as 'ritualized ritual' can lead to an 'exaggerated sense of stability... inured against the anguish of the world. ${ }^{39}$ Compare this with the experience of cathedral choirs who simply dread the Evensongs with long psalms appointed for the day within the Book of Common Prayer. Some verses are often likely to pass by some

\footnotetext{
${ }^{35}$ Ibid., 166.

${ }^{36}$ Ibid., 167.

${ }^{37}$ Consider the stability and permanence read in Ps 90 by Brueggemann and Bellinger, Psalms, 392. Divine eternity allows for the stability that seems initially to be challenged by the differences between repetitions of a text or prayer.

${ }^{38}$ See also Thiselton, New Horizons in Hermeneutics, 604ff.

${ }^{39}$ Begbie, Theology, 168.
} 
readers. There becomes little of the performative speech act, the word-changing-world. For something remembered, to 'go flat' means that it is no longer doing anything, in Hebraic terms: it just existed in the past and no longer has performative effect. A felicitous remembering, on the other hand, which can be inspired by close reflections, insightful means of study, and being open to encounter something of the past in new and transformative ways, can bring about just such freshness and effect change in the future.

(iii) 'Eucharistic repetition does not efface the temporal integrity of the initial appearance of the theme, or of its repetitions'.

Begbie goes on to posit:

The initial sounding of the theme is circumscribed and bounded. It begins and ends. It has its own completeness. A later repetition is not a prolongation or extension of the theme. Moreover, the subsequent repetition of the theme is not a matter of extracting the theme from its temporal relations and re-locating it, as it we could wrench it from 'that time' to 'this time'. It is embedded in a field of temporal contingencies... intrinsic to its identity... Identical repetition in the 'now' is impossible, not just because we are in a different temporal context, but because every musical event relates to a different hierarchical pattern of tension and resolution. $^{40}$

\footnotetext{
${ }^{40}$ Ibid., 169.
} 
Indeed, the text of the Bible has 'generated an enormous family of contrapuntal elaborations' ${ }^{41}$ in the Psalms alone for instance anyone who knows Ps 8:5 will hear its overtones in Ps 144:3. Oft-repeated Psalm 23 may evoke memories of prayers at a deathbed, sung as a hymn to the tune Crimond at a memorial service, or accompanied with drums and worship band to music by Stuart Townend. Beyond that, it features in films, resonates with images on the walls of catacombs in Rome, is cited in literature in many languages throughout the ages. Psalm 90 reminds many a British citizen of Remembrance Day celebrations according to Isaac Watts' tune, itself in turn inspiring the St. Anne's Fugue by J. S. Bach or settings of the words by Bairstow or Vaughan Williams. The repetitions, the recalling, of such well-known texts in different contexts mean that both the original texts, and their later and ongoing variations each have their own valuable integrities. Thus 'something new may even be said by repeating something that has already been said... repetition brings a new perspective on what is repeated; repetition makes the listener re-evaluate a statement or theme in the light of their restatement. ${ }^{42}$ Likewise, 'The earnest man is earnest precisely through the originality with which he returns in repetition. ${ }^{43}$ The way in which the "temporal integrity of the initial appearance of the theme, or of its repetitions' is not effaced by repetitive reading, singing, and praying of the Psalms is akin to understanding newness brought about by repetition and remembering.

\footnotetext{
${ }^{41}$ Rowan D. Williams, "Postmodern Theology and the Judgement of the World " in Postmodern Theology: Christian Faith in a Pluralist World, ed. Diogenes Allen and Frederic B. Burnham (San Francisco: HarperSanFrancisco, 1989), 93-4.

${ }^{42}$ D'Angour, Greeks and the New, 210.

${ }^{43}$ Søren Kierkegaard, The Concept of Anxiety: A Simple Psychologically Orienting Deliberation on the Dogmatic Issue of Hereditary Sin, ed. and trans. Reidar Thomte and Albert B. Anderson (Princeton: Princeton University Press, 1980), 149. Cited in D'Angour, Greeks and the New, 210.
} 
(iv) 'Eucharistic repetition means improvising'.

D'Angour, reflecting on the novelty of the early Greek bards, writes: 'Epic improvisation presents a paradigm of the creation of new material from a set of rules. Where does repetition end and creation begin? ${ }^{44}$ D'Angour's bards and Begbie's musicians both engage with their particular constraints, ranging from the acoustic, to other performers, and to the make-up of the audience. The constraints or rules are glorified in their repetition, enactment, and development. Just so the 'special' and the 'general' intertwine, as time and eternity are locked together in both the Psalms themselves and as texts reaching to the divine yet being performed in time. In the Psalter, the particularity of events and moments may be seen against the general theme of ongoing salvation history. Newness and repetition embrace in improvisation on old themes, as the theological significance of new creation is seen against the backdrop of repetition of past moments of salvation history. In a sense any repetition of a Psalm - or indeed any Biblical text raises issues akin to debates on what is 'authentic' performance of a piece of classical music. ${ }^{45}$ A spiritually-engaging performance of a Psalm or the Eucharist is itself an inspired authentic performance.

(v) 'Eucharistic repetition depends on and enables a particular kind of interpenetration of past, present, and future.'

Begbie's reflections on music and time open up fresh ways of regarding Eucharistic repetition:

${ }^{44}$ D'Angour, Greeks and the New, 211.

${ }^{45}$ F. Young, Virtuoso Theology: The Bible and Interpretation (Oregon: Wipf \& Stock, 2002), 21-5. 
Musical repetition is not... primarily a device whereby we in the (real) present attempt to preserve and carry forward into the unknown (and unreal) future something that otherwise might be lost in oblivion. In the midst of our fractured and distorted temporality we are given to participate in a temporality in which our past, present, and future can be at peace, co-inhere. Likewise... the Eucharist is the repeated embodiment of God's summons, provoking our attention, opening us out to Christ in such a way that what Christ was, suffered and did for us is made ever and again contemporary in its completeness for us who are still 'on the way', and, moreover, in such a manner that his past is known not merely as past to us but also as future. ${ }^{46}$

The Psalms in their remembrance and repetition offer a precursor of that, before and during the historical Christ's ministry. The Eucharist is a repeated re-enactment of salvific relationship between God and man. The Psalms too are repeated re-enactments of God's creation and covenant, which invite the pray-ers or audience to engage with the reality of relationship that is embodied in the discourse of memory and prayer in the Psalms, in such a way that time and eternity can be experienced as coming close to one another, if not indeed intersecting. The Psalms and the Eucharist are themselves even seen to intersect.

\section{Concluding the Dialogue}

The intersections between time and eternity, the Psalms and the Eucharist, are thus demonstrated by the intersections of thought of Eliade, Levine, and Begbie. Time is

\footnotetext{
${ }^{46}$ Begbie, Theology, 173.
} 
highlighted as a fascinating lens for reading the texts themselves, and also as a means of reflecting on hermeneutic methods.

Both within and beyond the two Psalms texts considered, Ps 90 beginning Book IV and Ps 145 perhaps once ending the entire Psalter, the Psalmist commits future generations to upholding Israel's relationship with God, in the existence of the text itself, in each and every reading by anyone of faith. ${ }^{47}$ The universality of the texts in style and content echoes the comprehensiveness of their message: an infinity which mortal limitations can only hope to intersect momentarily. The perpetual nature of these texts in their repeated enactment is profoundly performative: the relationship between God and man is perpetuated as praise is continued and communal memory and existence thereby secured. God is a continual dialogue-partner: both congregation and divinity are everpresent audience or addressee for these prayer-texts. The mortal pray-er engages with the infinite God, and repetition and remembrance allow time and eternity to connect. Time and memory are indissolubly bound in the texts of the Psalms and their ritual repetition. As such they inform present and future generations of the means and mechanics of prayer.

With such prayer texts and repetitive habits ingrained in the Jewish psyche (or even as Eliade would have it, the religious psyche), such an understanding of prayer and ritual offering an intersection between historical time and sacred time, or between time and eternity, would have been natural by the time of the historical Jesus's last supper. The institution of the Eucharist is built on the foundations of repetitive prayer for

${ }^{47}$ Cf. Gordon J. Wenham, Psalms as Torah: Reading Biblical Song Ethically (Grand Rapids: Baker Academic, 2012). 
remembering in Jewish worship as exemplified in the Psalms: prayer that is remembered and prayer that remembers, re-enacting time past to impact on the future, in the present.

So Eliade, conversation partner with Levine, has highlighted some of the importance of repetition and remembrance in ritual and sacred time; two Psalm texts have offered an outworking of this intersection; Begbie's study of theology and time through the lens of music has shown similar considerations to be at play in the Eucharist; and this has once again pointed back to the Psalms. Repetition and performance have indicated the relevance of the ever-changing audience and performers to any sacred text or ritual: so there is a vast amount of remembering going on, at a multiplicity of levels, in both the Psalms and the Eucharist. Pointing to the importance of continuation and preservation, complete with stability and permanence in creative tension with instability and improvisation, this study has contributed afresh to the tradition of textual transmission of prayers both scriptural and liturgical. Each text explored here contributes to the understanding of each other, despite their different historical and theological beginnings.

In terms of time beyond the texts, time as a means for reflecting on hermeneutics, the repetition of remembering in prayer improvises a new creation from the backdrop of old events, times remembered. Times are remembered and experienced afresh at each telling, at each listening. The texts may be remembered, read and improvised with novelty and change. The ongoing existence of the texts themselves through time allows for readings to change and develop, the old continually made new. The Psalms are a textual locus par excellence for the understanding of the importance of remembering in and of prayer, and as such are a prototype for the prayers of the New Testament. In the Psalms, as in the Eucharist, man was present to God, man is present to God, and man will 
be present to God. In the words of institution of the Eucharist, as in the Psalms, God was present, God is present, and God will be present. Through such sacred texts and experiences, the present time offers an intersection with eternity.

Such conclusions can inform not only an understanding of these selected texts and rituals, but also the dynamic possibilities of Biblical interpretation alive, continued, remembered, and authentically improvised, from one generation to another. This in itself is a dialogue that should not be concluded. 